\title{
Evaluation of four microbial bio-effectors for growth promotion and nutrient acquisition in bambara nut Vigna subterranea (L.) Verdc. (Fabales: Fabaceae) without mineral fertilization
}

\section{O. Oyewole ${ }^{1}$, Segun Oladele ${ }^{1,2, *}$, Moses Awodun $^{1}$ and Rasheedat Ajala $^{1}$}

${ }^{1}$ Department of Crop, Soil and Pest Management. Federal University of Technology. Akure PMB 704. Ondo State. Nigeria

${ }^{2}$ Department of Agronomy. Adekunle Ajasin University. Akungba Akoko PMB 01. Ondo State. Nigeria. Email: segunoladele14@gmail.com.

\begin{abstract}
This study seek to evaluate the potential of four BEs (Azotobacter, Azospirillum, Rhizobium and Arbuscular mycorrhizae fungi (AMF)) without complementary inorganic fertilizer in promoting plant growth and nutrient uptake in contrasting soil types. Field studies set up in completely randomized design (CRD) were conducted in Southwestern Nigeria using bambara groundnut Vigna subterranea (L.) Verdc. (Fabales: Fabaceae) as test crop sown on a sandy loam and clay loam alfisol. Result indicates that performance of inoculated BEs in improving bambara nut growth and nutrient uptake did not differ according to soil types. Promising results were obtained with all BEs with Rhizobium, $A M F$ and Azospirillum showing exceptional performance respectively across all measured parameters. These BEs are recommended for adoption by local farmers in the study area to optimize bambara nut performance with the aim of reducing dependence on inorganic fertilizers and improving fertilizer use efficiency.
\end{abstract}

Keywords: Bio-inoculants; Azotobacter; Azospirillum; Rhizobium; Arbuscular mycorrhizae fungi.
Received

October 27, 2018

Accepted

December 23, 2018

Released

December 31, 2018

Full Text Article

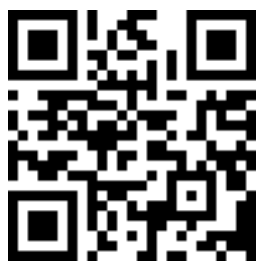

ORCID

() 0000-0001-6565-7635

0. O. Oyewole

(1) 0000-0002-7589-8658 Segun Oladele

(1) 0000-0004-8567-9675

Moses Awodun

(1) 0000-0003-5567-6687

Rasheedat Ajala 


\section{Introduction}

Crop production in Sub-Saharan Africa (SSA) is becoming increasingly difficult as a result of drought and low soil fertility (Nyanmangara and Nyagumbo, 2010; Awopegba et al., 2017). Excessive use of inorganic fertilizers has triggered several environmental problems such as release of greenhouse gases which depletes the ozone layer pollution of water resources, destruction of micro-organisms, and acidification of water and soil as well as leading to degrading of soil physical properties caused by low organic matter levels and nutrient imbalance (Nottidge, Ojeniyi and Aswalam, 2005; Akingbola et al., 2016).

Increasing attention is being devoted to the negative impact of highinput agricultural systems and more studies are focusing on alternative methods of producing sufficient food in a sustainable and environmentally efficient manner. A variety of technological approaches have been investigated with the intention of cutting down fertilizer use and increasing fertilizer efficiency in different agro-ecosystems. These approach includes including breeding plant varieties with better nutrient uptake efficiency (Lynch and Brown 2001), changing fertilizer application method and timing (Dunbabin et al., 2009), and application of soil organisms with plant growth-promoting potential Cladele and Awodun, 2014; Oladele, 2015; Awodun et al., 2017; Oladele and Ayodele, 2017).

Microbial bio-effectors (BEs), commonly called biofertilizers are gaining importance and can reduce the use of chemical fertilizers, being ecological friendly and products obtained from non-toxic sources (Sharma, et al., 2007). The BEs fixes nutrients through the natural processes of nitrogen fixation, solubilizing phosphorus and stimulating plant growth through the synthesis of growth-promoting substances. These effects are based on different mechanisms, for example, the control of plant pathogens either by stimulation of the plant's defense mechanisms or by microbial antagonism, stimulating the plant's growth hormone production such as auxins or cytokinins indirectly or by producing directly hormone-like compounds (Oladele, 2015; Awodun et al., 2017). Some BEs helps to increase phosphatase activities in the soil and also have the ability to liberate P from soil colloids and minerals and from P-fertilizers (Jastrzebska et al., 2016). Although BEs has shown the potential to promote plant growth, their performance could be affected by some biotic and abiotic factors. Furthermore, their introduction to soils could lead to competition with indigenous occurring microorganisms which sometimes limit the survival of introduced BEs (BuddrusSchiemann, 2010). This indicates that more studies are required to establish the conditions under which BEs can best show plant growth-promoting effects. Bambara nut is the second most important food legume and the third food crop, after maize and groundnut, grown by small-scale farmers in many African countries (Yao et al., 2015). In recent years, the high price of meat and fish has led to increased cultivation of the legume as an excellent source of protein (19\%) in developing countries (Baryeh, 2001; FAO, 2011).Thus, the crop has the potential to improve malnutrition and boost food availability in Africa. It is particularly suitable for marginal soils where other leguminous crops cannot be grown, a factor that has further made it to assume higher status in sub-Saharan Africa (FAO, 2011). Despite its high nutritional value and ability to replenish soil nutrients, bambara groundnut Vigna subterranea (L.) Verdc. (Fabales: Fabaceae) is still considered as one of the highly neglected and underutilized crop species in Africa (Dansi et al., 2012).

Studies have shown the responsiveness of legumes to inoculation with BEs, however little or no study has 
been conducted on response of bambara nut to inoculation with BEs.

With this deficit in literature, we evaluated the potential of four BEs; bacteria BE: Azotobacter, Azospirillum, Rhizobium and the fungal $\mathrm{BE}$ arbuscular mycorrhizae fungi (AMF).

We applied all BEs individually in order to study their effect on bambara nut growth and nutrient uptake with the sole aim of selecting the best performing $\mathrm{BE}$. We hypothesized that BE application will improve bambara nut growth and nutrient uptake through stimulation of growth hormones, nutrient fixation, solubilzation and mobilization of fixed nutrients in the soil.

\section{Materials and methods}

\section{Description of location and experimental site}

The study was conducted at two different experimental sites concurrently from October, 2015 to February, 2016 representing two different agro ecological zones in Ondo State, Southwestern Nigeria. The first location was at the Teaching and Research Farm of the Federal University of Technology Akure, in Akure South Local Government area of Ondo State, Nigeria while the second location was at the field experimental site of Benin-Owena River Basin Authority located at Araromi village in Akure North Local Government area of Ondo State. The soil type at araromi was a Typic Paleustalf clay loam alfisol, while the soil type at akure was kaolinitic Typic Paleustalf sandy loam alfisol. The experimental site at FUTA lies between latitude $7^{\circ} 16^{\prime \prime}$ and $7^{\circ} 18^{\prime \prime}$ North and longitude $5^{\circ} 09^{\prime \prime}$ and $5^{\circ} 11^{\prime \prime}$, while the second location lies between latitude $7^{\circ} .15^{\prime \prime}$ North and longitude $5^{\circ} 18^{\prime \prime}$ in the rain forest belt of the tropics. The zone is characterized by a gentle undulating elevation of about $1150 \mathrm{~m}-1250 \mathrm{~m}$ and has a tropical climate with distinct wet and dry seasons. A warm rainy season spans April to October followed by a hot dry period from November to March.

\section{Soil sampling and analysis}

Routine soil analysis was carried out by collecting soil samples randomly from sectioned parts of each experimental field at a depth of $0-15 \mathrm{~cm}$ and bulked into a composite sample for the determination of the physicochemical properties of the soil prior to planting and after crop harvest. The soil samples were air dried, crushed and sieved to pass through a $2 \mathrm{~mm}$ sieve for determination of particle size analysis using the hydrometer method as described by Bouyoucos (1962), Total nitrogen (TN) was analyzed using the macro Kjeldahl procedure as described by Jackson (1973); Soil organic carbon (SOC) was determined using the Walkley and Black procedure, soil $\mathrm{pH}$ was determined in soil/water ratio of $1: 2$ using a $\mathrm{pH}$ meter with glass electrode; Available phosphorus was determined by the Bray 1 method as described by Bray and Kurtz (1945); Exchangeable potassium (K), Calcium (Ca) and Magnessium ( $\mathrm{Mg}$ ) were determined by extraction with $1 \mathrm{M}$ ammonium acetate at $\mathrm{pH} 7.0$ and the amounts of $\mathrm{K}$ and $\mathrm{Ca}$ in the filtrate were determined using a Corning flame photometer with appropriate filter, while $\mathrm{Mg}$ was determined by using a Perkin-Elmer Atomic Absorption Spectrophotometer.

\section{Experimental design and layout}

The land used for the experiment was ploughed and ridged. The trial was laid out in randomized complete block design (RCBD). The total area for each experimental field at the locations was $31 \mathrm{~m} \times 13 \mathrm{~m}$. The field was divided into three blocks. Each block (3m) consists of five main plots ( $5 \mathrm{~m}$ per plot) with an alley of $1 \mathrm{~m}$ in-between blocks and subplots.

Treatments include arbuscular mycorrhizal fungi (AMF) $=\mathrm{T} 1$, Azospirillum $=\mathrm{T} 2$, Azotobacter $=\mathrm{T} 3$, Rhizobium $=\mathrm{T} 4$, and control (No BEs) $=$ T5. These treatments were randomly laid out sub-plots within the three blocks and 
replicated thrice giving a total of fifteen treatments. The BEs (Azotobacter, Azospirillium, Rhizobium and arbuscular myccorizzal fungi (AMF)) used in this study were sourced from the microbiological unit of the International Institute of Tropical Agriculture (IITA), Ibadan, Nigeria. The test crop (variety $\mathrm{T}_{\mathrm{V}} S_{U}$ 276) was also collected from the Legumes crop unit of the same institution. One seed of bambara nut was planted per hole on the ridge at a depth of $3-5 \mathrm{~cm}$ and at inter and intra row spacing of $75 \mathrm{~cm} \times 30 \mathrm{~cm}$ respectively. Emergence of the seedlings commenced seven days after planting. Crop management practices such as weeding and pest control was carried out as when due. However, there was minimal weed invasion at the experimental plots due to sowing of seeds on the ridges.

\section{Seed inoculation}

Seed inoculation with Azotobacter, Azospirillium, Rhizobium and AMF was carried out by dissolving $100 \mathrm{~g}$ of each of the inoculant in $20 \mathrm{~mL}$ of distilled water. The solution was divided into four parts. The test crop weighing about 500g was divided into four parts and each part was thoroughly mixed with each of the selected BEs inoculant in solution. Inoculated seeds were air dried overnight for $14 \mathrm{~h}$ and assigned randomly to the sub-plots in each block.

\section{Leaf sampling and analysis}

Leaf samples were collected on three plants per plot and mixed to form composite sample. Collected samples were oven-dried for $24 \mathrm{~h}$ at $70^{\circ} \mathrm{C}$, then ground in a Wiley-Mill. Tissue nitrogen content $(\mathrm{N})$ was determined by microkjeldahl digestion method. Samples were dry ashed at $500{ }^{\circ} \mathrm{C}$ for $6 \mathrm{~h}$ in a furnace and extracted using nitric-perchloric sulphuric acid mixture for determination of phosphorus (P), Potassium (K), Calcium (Ca) and Magnessium (Mg) and Sodium (Na). The $\mathrm{P}$ content was determined using Vanadomolybdate Colorimetry Method, $\mathrm{K}$ by flame photometer, $\mathrm{Ca}$ and $\mathrm{Mg}$ by EDTA titration method (AOAC, 1947).

\section{Data collection}

Data were collected on the following agronomic parameters: emergence count, establishment count, number of leaves at two weeks intervals (WAP), days to first flowering, days to $50 \%$ flowering, leaf length, leaf width, nodules count, number of lateral roots, tap root length and shoot and root weight (biomass). At maturity, two bambara nut plants were dug out per plot for nodules count, number of lateral roots, tap root length as well as root and shoot weight (biomass). The process involved initially wetting and digging of the soils around the plants to a depth of $50 \mathrm{~cm}$ with a cutlass making sure their roots were not disturbed. The plants were then pulled out gently, washed with water to remove soil particles on the roots, placed in polyethylene bags and transferred to the Department of Crop, Soil and Pest Management Laboratory for further analysis and observations.

\section{Statistical analysis}

Data collected were subjected to analysis of variance to determine effects of treatments on measured agronomic and nutrient uptake parameters using MINITAB statistical tool (17th edition). All data were checked prior to statistical analysis for the violation of ANOVA assumption, Tukey's HSD test was used to separate treatment means at $(\mathrm{p} \leq 0.05)$.

\section{Results}

\section{ties}

Soil physico-chemical proper-

Result indicates that soil from both experimental site were moderately acidic (Table 1). The $\mathrm{pH}$ value of the experimental site ranged between 5.56 to 5.86 which fall within the value considered suitable for the production of bambara groundnut according to Yao (2005) who reported the $\mathrm{pH}$ ranges most 
suitable for bambara nut cultivation, i.e. between 5 and 6.5 and should not be lower than 4.3 or higher than 7 . Soils at both sites were low in SOC (Table 1). The low SOC contents of both site is an indicator of poor water holding capacity and nutrient retention. Furthermore, TN and available $\mathrm{P}$ were found to be deficient at both locations beyond the critical limit. Other nutrients such as $\mathrm{Ca}$, was low at Akure with a content of 1.90 $\mathrm{cmol} / \mathrm{kg}$ while a value of $2.10 \mathrm{cmol} / \mathrm{kg}$ which is considered to be moderate was observed in Araromi. Low Mg content of $0.90 \mathrm{cmol} / \mathrm{kg}$ was observed in the two locations while moderate value of $\mathrm{Na}$ and $\mathrm{K}$ contents of $0.37 \mathrm{cmol} / \mathrm{kg}$ and 0.48 $\mathrm{cmol} / \mathrm{kg}$ were observed at araromi. Exchangeable $\mathrm{Na}$ was low $(0.2 \mathrm{cmol} / \mathrm{kg})$ in Araromi and a moderate $\mathrm{K}$ content value of $0.39 \mathrm{cmol} / \mathrm{kg}$ was recorded (Table 1).

Table 1. Pre-planting physico-chemical properties of the soil of the experimental site.

\begin{tabular}{lcc}
\hline \multirow{2}{*}{ Soil Parameters } & Values & \\
\cline { 2 - 3 } $\mathrm{pH}\left(\mathrm{H}_{2} \mathrm{O}\right)$ & Akure & Araromi \\
Organic carbon (\%) & 5.56 & 5.86 \\
Sand (\%) & 0.63 & 0.42 \\
Clay (\%) & 73.20 & 16.00 \\
Silt (\%) & 10.20 & 60.80 \\
Total nitrogen (g/kg) & 16.60 & 23.20 \\
Available P (mg/kg) & 0.06 & 0.05 \\
Calcium (cmol/kg) & 4.41 & 4.80 \\
Magnesium (cmol/kg) & 2.10 & 1.90 \\
Exch. Potassium (cmol/kg) & 0.90 & 0.90 \\
Sodium (cmol/kg) & 0.39 & 0.48 \\
\hline
\end{tabular}

Means are given with standard deviations of replicate measurements for soil $(n=3)$. ${ }^{*}$ Textural class $=$ Sandy loam.

\section{Effect of BEs on number of leaves of bambara groundnut}

Table 2 shows that bambara groundnut leaves responded positively to BEs inoculation. The number of leaves were significantly $(p<0.05)$ enhanced by the various BEs inoculants over the uninoculated treatment. In Akure, at 2 WAP the highest number of leaves were recorded in treatment inoculated with Azotobacter and was significantly $(\mathrm{p}<0.05)$ different from other treatments while the other treatments AMF, Azospirillium and Rhizobium recorded similar performance. At 4, 6 and 8 WAP all applied BEs showed similar trend in performance as they exerted no significant differences on the number of leaves but performed relatively higher than the control. However, at Araromi, at 2 WAP, the highest number of leaves was observed in the Azospirillium treated plots while no significant difference was observed amongst other applied BEs viz (AMF, Azotobacter and Rhizobium). At 4 WAP, there was no significant difference recorded in the performance of all BEs. At 6 WAP, the highest numbers of leaves were observed in Azospirillium and Rhizobium treated plots. At 8WAP, the performance observed in these BEs followed similar trend as observed in 6 WAP. 
Table 2. Effect of microbial bio-effectors (BEs) on number of leaves of bambara nut.

\begin{tabular}{|c|c|c|c|c|c|c|c|c|}
\hline \multirow{3}{*}{ BEsa } & \multicolumn{8}{|c|}{ Weeks'after'planting ${ }^{a}$} \\
\hline & \multicolumn{2}{|c|}{$2 \mathrm{x}$} & \multicolumn{2}{|c|}{$4 n$} & \multicolumn{2}{|r|}{$6 x$} & \multicolumn{2}{|r|}{$8 x$} \\
\hline & Akure ${ }^{a}$ & Araromix & Akured & Araromix & Akure & Araromin & Akure d & Araromin \\
\hline AMFu & $4.3^{\mathrm{ab}} \mathrm{a}$ & $4.7^{\mathrm{ab} a}$ & $17.1^{\text {and }}$ & $15.1^{\mathrm{a} a}$ & $39.4^{\mathrm{a} a}$ & $18.6^{\mathrm{ab} \mathrm{a}}$ & $46.6^{\mathrm{a} a}$ & $20.3^{\mathrm{ab}} \mathrm{a}$ \\
\hline Azospirillum & $4.5^{\mathrm{aba}}$ & $5.2^{\mathrm{a} a}$ & $17.6^{\mathrm{ad}}$ & $15.7^{\mathrm{ad}}$ & $41.8^{\mathrm{a} a}$ & $21.4^{\mathrm{a} a}$ & $45.1^{\mathrm{ad}}$ & $22.6^{\mathrm{a} a}$ \\
\hline Azotobacter & $4.7^{\mathrm{a} a}$ & $4.7^{\mathrm{ab} \mathrm{a}}$ & $18.4^{\mathrm{a} a}$ & $15.4^{\mathrm{ad}}$ & $39.2^{\mathrm{ad}}$ & $15.9^{\mathrm{ab}}$ & $44.3^{\mathrm{a} a}$ & $20.2^{\mathrm{ab} \mathrm{a}}$ \\
\hline Rhizobium a & $4.5^{\mathrm{ab} \mathrm{a}}$ & $4.9^{\mathrm{ab}}$ & $18.6^{\mathrm{ad}}$ & $14.7^{\text {a } a}$ & $41.6^{\mathrm{a} a}$ & $20.0^{\mathrm{a} \mathrm{a}}$ & $46.5^{\mathrm{a} a}$ & $22.7^{\text {ax }}$ \\
\hline Control.(No.BEs) & $4.1^{\mathrm{b} \mathrm{a}}$ & $4.2^{\mathrm{ba}}$ & $14.2^{\mathrm{b} \mathrm{a}}$ & $11.5^{\mathrm{b} a}$ & $26.4^{\mathrm{b} a}$ & $15.3^{\mathrm{b} a}$ & $32.5^{\mathrm{b} a}$ & $15.8^{\mathrm{cr}}$ \\
\hline
\end{tabular}

*Means followed by similar letters are not significantly different according to Tukey’s HSD test.

Effect of BEs on seedling emergence, establishment, days to first flowering, days to $\mathbf{5 0 \%}$ flowering and length of tap root at maturity

The result of the experiment showed that inoculation of bambara nut with BEs exerted no significant influence on parameters such as seedling emergence, seedling establishment, days to first flowering, days to $50 \%$ flowering and tap root length at maturity.

\section{Effect of BEs on the terminal leaflet length of bambara nut at flowering}

At both experimental sites, application of BEs influenced the terminal leaf length as significant increase $(p<0.05)$ in the BEs treated plot were recorded over the control throughout the growing period (Table 3 ). At Akure, the longest leaves were observed in Rhizobium treated plots (6.16) followed closely by Azotobacter (6.07) as no significant difference was observed between the two BEs while AMF and Azospirillum showed similar trends in their performance. At Araromi, the longest leaf was observed in the plot inoculated with Azotobacter (6.28), while no significant difference was recorded in the performance of AMF and Rhizobium treated plots.

Table 3. Effect of BEs on below ground biomass and nodule formation of bambara groundnut.

\begin{tabular}{|c|c|c|c|c|c|c|c|c|c|c|c|c|c|c|}
\hline \multirow[t]{2}{*}{ BEs } & \multicolumn{2}{|c|}{$\begin{array}{l}\text { Terminal leaflet } \\
\text { width }(\mathrm{cm})\end{array}$} & \multicolumn{2}{|c|}{$\begin{array}{l}\text { Terminal leaflet } \\
\text { length }(\mathrm{cm})\end{array}$} & \multicolumn{2}{|c|}{$\begin{array}{l}\text { Dry root weight } \\
(\mathrm{g})\end{array}$} & \multicolumn{2}{|c|}{$\begin{array}{c}\text { Dry shoot weight } \\
(\mathrm{g})\end{array}$} & \multicolumn{2}{|c|}{$\begin{array}{l}\text { Tap root length } \\
\text { (cm) }\end{array}$} & \multicolumn{2}{|c|}{$\begin{array}{c}\text { Number of lateral } \\
\text { roots }\end{array}$} & \multicolumn{2}{|c|}{$\begin{array}{c}\text { Number of root } \\
\text { nodules }\end{array}$} \\
\hline & Akure & Araromi & Akure & Araromi & Akure & Araromi & Akure & Araromi & Akure & Araromi & Akure & Araromi & Akure & Araromi \\
\hline AMF & $2.51^{\mathrm{a}}$ & $2.04^{\mathrm{ab}}$ & $6.02^{\mathrm{ab}}$ & $6.09 \mathrm{ab}$ & $1.43^{\mathrm{a}}$ & $0.66^{\mathrm{a}}$ & $23.3^{\mathrm{a}}$ & $8.3^{\mathrm{a}}$ & $12.7^{\mathrm{a}}$ & $11.9^{a}$ & $18.4^{a}$ & $21.1^{\mathrm{ab}}$ & $9.5^{\mathrm{a}}$ & $12.6^{\mathrm{ab}}$ \\
\hline Azospirillium & $2.67^{\mathrm{a}}$ & $1.98^{\mathrm{ab}}$ & $6.00^{\mathrm{ab}}$ & $5.96^{\mathrm{b}}$ & $1.17^{\mathrm{a}}$ & $0.56^{\mathrm{ab}}$ & $13.8^{\mathrm{b}}$ & $6.8^{\mathrm{b}}$ & $12.5^{\mathrm{a}}$ & $13.8^{\mathrm{a}}$ & $21.5^{\mathrm{a}}$ & $24.0^{\mathrm{a}}$ & $9.8^{\mathrm{a}}$ & $16.2^{\mathrm{a}}$ \\
\hline Azotobacter & $2.75^{\mathrm{a}}$ & $1.99 \mathrm{ab}$ & $6.07^{a}$ & $6.28^{\mathrm{a}}$ & $1.21^{\mathrm{a}}$ & $0.55^{\mathrm{ab}}$ & $16.5^{\mathrm{ab}}$ & $7.0^{\mathrm{b}}$ & $12.0^{\mathrm{a}}$ & $13.1^{\mathrm{a}}$ & $22.7^{\mathrm{a}}$ & $19.9 \mathrm{ab}$ & $9.7 \mathrm{a}$ & $13.9 \mathrm{ab}$ \\
\hline Rhizobium & $2.64^{\mathrm{a}}$ & $1.88^{\mathrm{b}}$ & $6.16^{\mathrm{a}}$ & $6.20^{\mathrm{ab}}$ & $1.34^{\mathrm{a}}$ & $0.59^{\mathrm{a}}$ & $16.1^{\mathrm{ab}}$ & $5.9^{\mathrm{b}}$ & $12.3^{\mathrm{a}}$ & $13.7^{\mathrm{a}}$ & $17.8^{\mathrm{a}}$ & $22.1^{\mathrm{ab}}$ & $10.2^{\mathrm{a}}$ & $13.4 \mathrm{ab}$ \\
\hline Control & $2.46^{\mathrm{a}}$ & $2.14^{\mathrm{a}}$ & $5.62^{b}$ & $5.62^{c}$ & $1.38^{\mathrm{a}}$ & $0.40^{\mathrm{b}}$ & $18.6^{\mathrm{ab}}$ & $4.5^{c}$ & $14.7^{\mathrm{a}}$ & $12.6^{\mathrm{a}}$ & $9.8^{\mathrm{b}}$ & $15.12^{\mathrm{b}}$ & $6.0^{\mathrm{b}}$ & $8.7^{b}$ \\
\hline
\end{tabular}

Means in the same column followed by the same letter are not significantly different at $(\mathrm{P}<0.05)$ according to Tukey's HSD test.

Effect of BEs inoculation on lateral root produced by bambara nut at maturity

Application of BEs exerted significant increase on the number of lateral roots produced by bambara nut (Table 3). At Akure, all applied BEs viz
(AMF, Azospirillum, Azotobacter and Rhizobium) showed similar trend in performance as no significant difference was observed amongst these treatments. However, at Araromi, the highest number of lateral roots (24.0) was observed in bambara nuts treated with 
Azospirillum, while the other three BEs showed similar trends in performance.

\section{Effect of BEs on below ground biomass of bambara nut}

At Akure, BEs exerted no effect on the bambara nut root weight as no significant difference was recorded between the inoculated bambara nuts and the un-inoculated bambara nut (Table 3). However, at Araromi, the application of BEs significantly $(\mathrm{p}<0.05)$ influenced the weight of bambara nut root. The highest root weight was observed in the AMF treated plot (0.66) followed closely by Rhizobium (0.59). The least performance was however observed in Azotobacter treated plot, while all applied BEs performed better and was significantly higher than the control (un-inoculated treatment). With respect to shoot weight, AMF treated plot (23.3) recorded the highest shoot weight at Akure followed by Azospirillum treated plot. However, values between this two BEs were statistically significant. Surprisingly, Azotobacter and Rhizobium treated bambara nuts did not higher shoot weight than the control. At Araromi, AMF also recorded the highest shoot weight which was significantly different while no significant difference ( $p<0.05)$ was recorded amongst the other three biofertilizers (Azospirillium, Azotobacter and Rhizobium). However, all inoculated bambara nuts performed better than un-inoculated nuts.

\section{Effect of BEs on nodule formation of bambara nut \\ Nodule formation in bambara \\ nuts was significantly $(\mathrm{p}<0.05)$} influenced by the applied BEs (Table 3). BEs inoculation significantly increased the nodule formation of bambara nut over that of the control at the two experimental locations. However, no significant difference was observed in the performance of all BEs at Akure, while at Araromi, bambara nut with the highest number of nodules (16.2) was observed in the plot treated with Azospirillum.

\section{Effect of BEs on Leaf nutrient content of bambara nut}

Table 4, shows the general effect of BEs on bambara nut nutrient uptake. At Akure, Azospirillum inoculated bambara nuts performed better than other BEs as it recorded the highest value of $\mathrm{N}, \mathrm{P}, \mathrm{K}$ and $\mathrm{Mg}$ leaf content. Azotobacter had the highest value (8.67 $\mathrm{cmol} / \mathrm{kg}$ ) in Na content while the highest Ca mean value was recorded under Rhizobium. At Araromi, Azospirillum and Rhizobium had higher leaf $\mathrm{N}$ content when compared to the control treatment, while the highest $\mathrm{P}$ and $\mathrm{Mg}$ content were observed in Rhizobium inoculated bambara nuts. Azotobacter inoculated nuts had the highest leaf $\mathrm{Ca}$ content while there was no significant difference among all the BEs performance with respect to $\mathrm{K}$ and $\mathrm{Na}$ leaf content (Table 4).

Table 4. Effect of microbial bio-effectors (BEs) on leaf nutrient content of bambara nut.

\begin{tabular}{|c|c|c|c|c|c|c|c|c|c|c|c|c|}
\hline \multirow{2}{*}{ BEs } & \multicolumn{2}{|c|}{$\mathrm{N}(\%)$} & \multicolumn{2}{|c|}{$P(\%)$} & \multicolumn{2}{|c|}{$\mathrm{K}(\%)$} & \multicolumn{2}{|c|}{ Ca (\%) } & \multicolumn{2}{|c|}{$\operatorname{Mg}(\%)$} & \multicolumn{2}{|c|}{$\mathrm{Na}(\%)$} \\
\hline & Akure & Araromi & Akure & Araromi & Akure & Araromi & Akure & Araromi & Akure & Araromi & Akure & Araromi \\
\hline AMF & $1.37 \mathrm{~b}$ & $1.30^{\mathrm{ab}}$ & $5.41^{b}$ & $3.61^{\mathrm{b}}$ & $6.51^{b}$ & $6.58^{\mathrm{a}}$ & $7.02^{\mathrm{a}}$ & $7.86^{\mathrm{ab}}$ & $1.94 \mathrm{~b}$ & $1.30^{\mathrm{b}}$ & $2.39 \mathrm{~b}$ & $2.40^{\mathrm{a}}$ \\
\hline Azospirillum & $1.49 \mathrm{a}$ & $1.37 \mathrm{a}$ & $5.69^{\mathrm{a}}$ & $3.57 \mathrm{~b}$ & $6.62^{\mathrm{a}}$ & $6.88^{a}$ & $7.60^{\mathrm{b}}$ & $7.46^{\mathrm{ab}}$ & $2.00^{\mathrm{a}}$ & $1.37 \mathrm{ab}$ & $2.38^{\mathrm{b}}$ & $2.68^{\mathrm{a}}$ \\
\hline Azotobacter & $1.31^{\mathrm{b}}$ & $1.27 \mathrm{~b}$ & $5.11^{\mathrm{c}}$ & $3.95^{\mathrm{ab}}$ & $6.06^{c}$ & $6.92^{\mathrm{a}}$ & $6.00^{\mathrm{d}}$ & $8.28^{a}$ & $1.74^{\mathrm{c}}$ & $1.30^{\mathrm{b}}$ & $2.75^{\mathrm{a}}$ & $2.54^{\mathrm{a}}$ \\
\hline Rhizobium & $1.33^{c}$ & $1.39 \mathrm{a}$ & $5.07 \mathrm{c}$ & $4.76^{\mathrm{a}}$ & $6.46^{b}$ & $6.75^{\mathrm{a}}$ & $8.67 \mathrm{a}$ & $7.01^{b}$ & $1.95^{b}$ & $1.39^{\mathrm{a}}$ & $2.00^{c}$ & $2.43^{\mathrm{a}}$ \\
\hline Control (No BEs) & $1.05^{\mathrm{d}}$ & $1.16^{c}$ & $2.11^{\mathrm{d}}$ & $2.19 c$ & $4.75^{\mathrm{d}}$ & $5.88^{\mathrm{b}}$ & $3.67 c$ & $4.83^{c}$ & $0.84^{\mathrm{d}}$ & $1.15^{c}$ & $1.78^{\mathrm{d}}$ & $1.89 \mathrm{~b}$ \\
\hline
\end{tabular}

*Means followed by similar letters are not significantly different according to Tukey's HSD test. 

status

\section{Effect of BEs on soil nutrient}

At Akure, the highest level of soil $\mathrm{pH}, \mathrm{SOC}$ and available $\mathrm{K}$ were recorded in Rhizobium treatment. The highest level of TN was observed in AMF while there was no significant difference in the level of available P observed in Azospirillium and Azotobacter. At Araromi, the highest soil $\mathrm{pH}$ unit was observed in Azospirillium. However, there was no significant difference between amongst AMF, Azospirillium and Rhizobium with respect to SOC. Similar trend as recorded in Akure was observed at araromi with respect to TN as AMF also had the highest TN level. Furthermore, there was no significant difference observed across levels of available $\mathrm{K}$ amongst all treatments. However, all treatments performed better than the control (no BEs) (Table 5).

Table 5. Effect of microbial bio-effectors (BEs) on soil nutrient status after bambara nut harvest.

\begin{tabular}{|c|c|c|c|c|c|c|c|c|c|c|}
\hline \multirow{2}{*}{ BEs } & $\mathrm{pH}$ & $\left(\mathrm{H}_{2} \mathrm{O}\right)$ & SOC & $(\%)$ & Total & $\mathrm{N}(\mathrm{g} / \mathrm{kg})$ & Avail. & $P(\mathrm{mg} / \mathrm{kg})$ & Avail. & $\mathrm{K}(\mathrm{cmol} / \mathrm{kg})$ \\
\hline & Akure & Araromi & Akure & Araromi & Akure & Araromi & Akure & Araromi & Akure & Araromi \\
\hline $\mathrm{AMF}$ & $5.80^{\mathrm{a}}$ & $5.90^{\mathrm{b}}$ & $0.71^{c}$ & $0.79 \mathrm{a}$ & $0.31^{\mathrm{a}}$ & $0.34^{\mathrm{a}}$ & $3.95^{b}$ & $5.78^{\mathrm{a}}$ & $0.52^{\mathrm{a}}$ & $0.53^{\mathrm{ab}}$ \\
\hline Azospirillum & $5.60^{\mathrm{b}}$ & $5.89 \mathrm{~b}$ & $0.79 \mathrm{bc}$ & $0.80^{\mathrm{a}}$ & $0.19^{b}$ & $0.20^{\mathrm{b}}$ & $4.03^{\mathrm{a}}$ & $3.99 \mathrm{~b}$ & $0.52^{\mathrm{a}}$ & $0.50^{\mathrm{b}}$ \\
\hline Azotobacter & $5.70^{c}$ & $5.87 \mathrm{~b}$ & $0.72^{c}$ & $0.74^{\mathrm{ab}}$ & $0.18^{\mathrm{b}}$ & $0.17 \mathrm{~b}$ & $4.00^{\mathrm{a}}$ & $4.52^{\mathrm{ab}}$ & $0.50^{\mathrm{a}}$ & $0.58^{\mathrm{a}}$ \\
\hline Rhizobium & $5.80^{\mathrm{a}}$ & $5.87 \mathrm{~b}$ & $0.81^{\mathrm{a}}$ & $0.78^{\mathrm{a}}$ & $0.17 \mathrm{~b}$ & $0.15^{b}$ & $3.91^{b}$ & $3.86^{b}$ & $0.55^{\mathrm{a}}$ & $0.50^{\mathrm{b}}$ \\
\hline Control (No BEs) & $5.53^{b}$ & $5.87 \mathrm{~b}$ & $0.66^{c}$ & $0.68^{\mathrm{b}}$ & $0.05^{c}$ & $0.05^{c}$ & $3.50^{\mathrm{c}}$ & $4.14 \mathrm{~b}$ & $0.31^{\mathrm{b}}$ & $0.40^{c}$ \\
\hline
\end{tabular}

*Means followed by similar letters are not significantly different according to Tukey's HSD test.

\section{Discussion}

Findings from our study showed that application of BEs influenced observed parameters such as; number of root nodules, number of lateral root, root and shoot weight, width and length of leaf at flowering as well as leaf numbers. This result is in agreement with the report of Smith and Read (1997), Ngakou (2007), Ngakou et al. $(2008 ; 2012)$ who also observed enhanced growth performance of plant inoculated with BEs.

This enhanced performance is attributed to increased nutrient uptake in inoculated plants. Furthermore, observed increase in number of leaves and delayed leaf shedding in bambara nuts inoculated with BEs in our study could be ascribed to production of phytohormones like indole acetic acid (IAA), gibberellins and cytokines as reported by Rao Bhaskara and Charyulu (2005).
This observation was in agreement with the previous findings of Senthikumar and Sivagurunathan (2012) and Priya and Geetham (2015). On the contrary, inoculation of bambara nuts with BEs did not exert significant influence on establishment count, days to first flowering, days to $50 \%$ flowering, length of tap roots at maturity and seedling emergence count.

However, we observed that after sowing inoculated bambara nuts, germination occurred a week later although this was within the range of 7-15 days reported by Swanevelder (1998), or 7-10 days period reported as necessary for germination of bambara groundnut by Yao et al. (2005). Our observation was also corroborated by Ngakou et al. (2012). Furthermore, Brink et al. (2006) reported that flowering in bambara nut occurs within 30 to 55 days after sowing. The observation in this study was in agreement with this submission but in contrast to the observation of Ocran et al. (1998) who 
reported early flowering in bambara nut within 42 days which could have been induced by abiotic stress.

Inoculation of bambara nuts with BEs in our study did not influence days to $50 \%$ flowering. Days to $50 \%$ flowering as observed in this study was between 39 to 43 days after planting which corroborates the report of Berchie et al. (2010) which revealed days to $50 \%$ flowering at between 39-41 days after planting. However, this observation was in contrast to the findings of Ngaoku et al. (2012) which reported that day to $50 \%$ flowering for bambara nut varies with cultivars and the environmental condition of the growing area.

Inoculation of bambara nuts with BEs in our study did not significantly influence the tap root length and this result is in contrast to the findings of Priya and Geetham (2015) which reported an increase in the root length of plants inoculated with BEs. Findings from our study shows that bambara nuts inoculated with BEs, irrespective of the treatment had higher effective nodules than the un-inoculated bamabara nuts. This finding are in agreement with the report of Chibeba et al. (2015), Siddiqui et al. (2014), Naderifar and Daneshian (2012), Sarker et al. (2012), Patra and Bhattacharyya (1997).

Nodulation plays a critical role in $\mathrm{N}$ fixation by leguminous crops. Nodule growth and function require lightdependent photosynthate, which is an important parameter under study, since nodule is the main source of biological nitrogen fixation by plant growth promoting Rhizobacteria and AMF inoculants in legumes. However, observed nodule formation in un-inoculated bambara nuts although lower than inoculated nuts suggests the presence of native strains of BEs such as Rhizobacteria and Mycorrhiza fungi in the experimental soil. It is pertinent to note that these native BEs exerted less influence on nodule formation in the uninoculated nuts suggesting their less competitiveness than the introduced ones (Ngakou, 2007). This also demonstrates the specific interaction existing between these microbial symbionts and the host plant.

The uptake or accumulation of nutrients like $\mathrm{N}, \mathrm{P}$ and $\mathrm{K}$ reported in this study was in agreement with the findings of Baqual and Das (2006) and Qureshi et al. (2009) who all reported an increase in the content of $\mathrm{N}$ and $\mathrm{P}$ available in the soil, while Khosravi et al. (2009) reported an increase in soil and leaf N, P, K, Ca content. The trends in increased nutrients uptake observed in inoculated bambara nuts and subsequent increase nutrients in the soil may be due to the capability of the BEs to mobilize and transform essential nutrient elements in the soil from non-available form to available form through biological processes (Chandrasekar et al., 2005; Selvakumar, 2009) such as nitrogen fixation, solubilizing phosphorus and stimulating plant growth through the synthesis of growth promoting substances. El-Shanshorey (1995) also reported that BEs increased nutrient concentration and uptake by cereal crops, which lead to luxurious growth and better crop development.

The slight increase in all nutrient components observed in the control (uninoculated bamabara nuts) though lower than BEs inoculated nut could also be as a result of bambara groundnut ability to naturally fix atmospheric nitrogen. According to Baudoin and Mergeai (2001), bambara groundnut as with all legumes is also capable of symbiosis with nitrogen fixing bacteria belonging to the genus rhizobium. The performance of introduced BEs could be explained by the fixation of nitrogen, production of plant growth promoters, decreasing ethylene production (although not determined in our study) and solubilisation of fixed minerals such as phosphorus (Karthikeyan et al., 2008).

Thus, the effect of BEs in this study can be justified, at least partly, to the ability of BEs to help fix atmospheric nitrogen. The increase in soil $\mathrm{pH}$ after 
bambara nut harvest as observed in our study especially at akure was in agreement with the findings of Ngakou et al. (2012). This slight increase in soil pH towards neutrality might suggest the fixation of $\mathrm{H}^{+}$ions to colloids following the transformation of non useable to useable form of phosphorus by the host plant as well as mineralization and subsequent release of basic cations trapped in the soil (Ndéye, 2002). The slight increase in SOC as observed in this study especially in Rhizobium, Azospirillum and AMF treatments are in agreement with the findings of Dębska et al. (2016) who reported significant changes in quality and quantity of SOC in soils used to grow crops continuously inoculated with BEs. However, this was in contrast to the findings of Ngakou et al. (2012) which reported slight decrease in organic matter content.

\section{Conclusion}

We have observed in our experiment, that differing soil types had no influence on BEs performance. Of all tested BEs, Rhizobium, $A M F$ and Azospirillum respectively were the most promising exerting their influence on bambara nut growth, biomass production and nutrient uptake. The mechanisms behind bambara nut performance could be ascribed to improved root growth (volume of soil explored for nutrients uptake), fixation of $\mathrm{N}$ and mobilization of nutrients such as $\mathrm{P}$ induced by introduced BEs. Future studies should focus on complementing BEs with organic and inorganic fertilizers, selecting compatible BEs strain with fertilizers and how this combination interacts with crop and soil properties. Furthermore, elucidating mechanisms behind BEs performance together with new studies focusing on more diverse soils will provide insights on how to successfully adopt BEs for sustainable crop production.

\section{Conflict of interest}

Authors declare that they have no conflict of interests.

\section{References}

Akingbola, O. O.; Adeyemo, A. J.; Oladele, S. O.; Ojeniyi, S. O. Physical status and infiltration dynamics of tropical alfisol as affected by poultry manure. Applied Tropical Agriculture, v. 21, no. 3, p. 102-111, 2016.

AOAC-Association of Official Analytical Chemist. Official methods of analysis of the Association of Official Analytical Chemist International. 16. ed. Arlington, VA: AOAC International, 1947.

Awopegba, M.; Oladele, S.; Awodun, M. Effect of mulch types on nutrient composition, maize (Zea mays L.) yield and soil properties of a tropical Alfisol in Southwestern Nigeria. Eurasian Journal of Soil Science, v. 6, no. 2, p. 121-133, 2017. https://doi.org/10.18393/ ejss. 286546

Baqual, M. F.; Das, P.K. Influence of biofertilizers on macronutrient uptake by the mulberry plant and its impact on silkworm bioassay. Caspian Journal of Enveronmental Sciences, v. 4, p. 98-109, 2006.

Baryeh, E. A. Physical properties of bambara groundnuts. Journal of Food Engineering, v. 47 , p. 321-326, 2001. https://doi.org/ 10.1016/s0260-8774(00)00136-9

Baudoin, J. P.; Mergeai, G. Grain legumes. In: Raemaeker, R. (Ed.). Crop production in Tropical Africa. Brussels: Directorate Generale for International Cooperation, 2001. p. 313-317.

Berchie, J. N.; Sarkodie, A. J.; Adu-Dapaah, H.; Agyemang, A.; Addy, S.; Asare, E.; Donkor, J. Yield evaluation of three early maturing bambara groundnut (Vigna subterranean L. Verdc) land races at CSIR-Crops Research Institute-Kumasi, Ghana. Journal of Agronomy, v. 9, p. 175-179. 2010.

Bouyoucos G. J. Hydrometer method improved for making particle size analysis. Agronomy Journal, v. 54, p. 464-465, 1962.

Bray, R. H.; Kurtz, L. Determination of total, organic, and available forms of phosphorus in soils. Soil Science, v. 59, no. 1, p. 39-46, 1945. 
Brink, M.; Ramolemana, G. M.; Sibuga, K. P. Vigna subterranea (L.) Verdc. Record from Protabase. Brink, M.; Belay, G. (Eds.). PROTA (Plant Resources of Tropical Africa). Wageningen, Netherlands: PROTA, 2016.

Buddrus-Schiemann, K.; Schmid, M.; Schreiner, K.; Welzl, G.; Hartmann, A. Root colonization by Pseudomonas sp. DSMZ 13134 and impact on the indigenous rhizosphere bacterial community of barley. Microbial Ecology, v. 60, no. 2, p. 381-393, 2010. https://doi.org/10.1007/s00248-0109720-8

Chandrasekar, B. R.; Ambrose, G.; Jayabalan $\mathrm{N}$. Influence of biofertilizers growth and soil health supporting bacteria. Current Science, v. 89, p. 136-143, 2005.

Chibeba, A. M.; Guimarães, M. F.; Brito; O. R.; Nogueira, M. A.; Araujo, R. S.; Hungria, M. Coinoculation of soybean with Bradyrhizobium and Azospirillum promotes early nodulation. American Journal of Plant Sciences, v. 6, p. 1641-1649, 2015. https://doi.org/10.4236/ ajps.2015.610164

Dansi, A.; Vodouhe, R.; Azokpota, P. Diversity of the neglected and underutilized crop species of importance in Benin. The Scientific World Journal, v. 3, p. 932-947, 2012. https://doi.org/10.1100/2012/ 932947

Dębska, B.; Długosz, J.; Piotrowska-Długosz, A; Banach-Szott, M. The impact of a biofertilizer on the soil organic matter status and carbon sequestration: Results from a field-scale study. Journal of Soils and Sediments, v. 16, p. 2335-2343, 2016. https://doi.org/10.1007/s11368-016-14305

Dunbabin, V.; Armstrong, R.; Officer, S.; Norton R. Identifying fertiliser management strategies to maximise nitrogen and phosphorus acquisition by wheat in two contrasting soils from Victoria, Australia. Australian Journal of Soil Research, v. 47, p. 74-90, 2009. https://doi.org/10.1071/ SR08107

El-Shanshorey, A. A. Interaction of Azotobacter chroococcum, Azospirillum brasilense and Streptomyces mutabilis in relation to their effect wheat development. Journal of Agronomy and Crop Science, v. 175, no. 2, p. 119-127, 1995. https://doi.org/10.1111/j.1439-037X.1995. tb01137.x
FAO. Food and Agriculture Organization. Statistical Database. 2011. Available from: <http://faostat.fao.org>. Accessed on: Apr. 23, 2018.

Jackson M. L. Soil chemical analysis. Englewood Cliffs, USA: Prentice Hall Grice, 1973.

Jastrzębska, M.; Kostrzewska, M.; Treder, K.; Jastrzębski, W.; Makowski, P. Phosphorus biofertilizers from ash and bones: Agronomic evaluation of functional properties. Journal of Agricultural Science, v. 8, no. 6, p. 58-70, 2016.

Karthikeyan, B.; Jaleel, C. A.; Zhao, C. X.; M. Joe, M.; Srimannarayan, J.; Deiveekasundaram, M. AM fungi and phosphorus levels enhances the biomass yield and ajmalicine production in Catharanthus roseus. Eurasian Journal of Biosciences, v. 2, p. 26-33, 2008.

Khosravi; H.; Samar, S. M.; Fallahi, E.; Davoodi, H.; Shahabian, M. Inoculation of 'Golden Delicious' apple trees on M9 rootstock with Azotobacter improves nutrient uptake and growth indices. Journal of Plant Nutrition, v. 32, p. 946-953, 2009. https://doi.org/10.1080/019041609028707 13

Lynch, J. P.; Brown, K. M. Topsoil foraging: An architectural adaptation of plants to low phosphorus availability. Plant Soil, v. 237, no. 2, p. 225-237, 2001. https://doi.org/ 10.1023/A:1013324727040

Naderifar, M.; Daneshian, J. Effect of different nitrogen and biofertilizers effect on growth and yield of Brassica napus L. International Journal of Agriculture and Crop Sciences, v. 8, p. 478-482, 2012.

Ndéye, F. D. Utilization of Rhizobium inoculum for growth of common bean (Phaseolus vulgaris) in Senegal. Dakar, Senegal: University Cheikh Anta Diop, 2002. (Doctorate thesis).

Ngakou, A. Potentials of selected biofertilizers and a mycoinsecticides in managing Megalurothrips sjostedti and improving cowpea production in Cameroon. Buea: University of Buea, 2007. (Ph. D. thesis).

Ngakou, A.; Megueni, C.; Makalao, M. M.; Nwaga, D.; Taine, J.; Ndjouenkeu, R. Changes in the physico-chemical properties of soil and harvested soybean seeds in response to soil solarization and bradyrhizobial inoculation. Archives of Agronomy and Soil Science, 
v. 54, p. 189-202, 2008. https://doi.org/ 10.1080/03650340701793579

Ngakou, A.; Ngo Nkot, L.; Doloum, G.; Adamou, S. Mycorrhiza-Rhizobium-Vigna subterranea dual symbiosis: Impact of microbial symbionts for growth and sustainable crop yield improvement. International Journal of Agriculture and Biology, v. 14, no. 6, p. 915-921, 2012.

Nottidge, D. O.; Ojeniyi, S. O.; Asawalam, D. 0. Comparative effects of plant residues and NPK fertilizer on soil properties in a humid soil. Nigerian Journal of Soil Science, v. 15, p. 9-13, 2005.

Nyamangara, J.; Nyagumbo I. Interactive effects of selected nutrient resources and tied-ridging on plant growth performance in a semi-arid smallholder farming environment in Central Zimbabwe. In: Bationo, A.; Waswa, B.; Okeyo, J.; Maina, F.; Kihara, J. (Eds.). Innovations as key to the green revolution in Africa. Dordrecht: Springer, 2010. https://doi.org/10.1007/ 978-90-481-2543-2_36

Ocran, V. K.; Delimini, L. L.; Asuboah, R. A.; Asiedu, E. A. Seed management: Manual for Ghana. Accra, Ghana: MOFA, 1998.

Oladele, S. O. Mycorrhizal fungus (Glomus mossae) inoculation effects on performance and root biomass development of cacao seedlings in the nursery. Agriculture and Forestry, v.61, no. 3, p.69-76, 2015. https://doi.org/10.17707/AgricultForest.61. 3.07

Oladele, S. O.; Awodun, M. A. Influence of mycorrhizae and Rhizobium inoculation on growth, nutrient uptake and proximate composition of upland rice cultivars. Journal of Natural Science Research, v. 4, no. 24, p. 42-52, 2014.

Oladele, S.; Ayodele, O. Glyphosate, 1,1'dimethyl-4,4'-bipyridinium dichloride and atrazine induces changes in soil organic carbon, bacterial and fungal communities in a tropical alfisol. Eurasian Journal of Soil Science, v. 6, no. 3, p. 238-248, 2017. https://doi.org/10.18393/ejss.292581

Patra, D. K.; Bhattacharyya, P. Influence of root nodule Bacterium on nitrogen fixation and yield of mungbean. Journal of Mycopathology Research, v. 35, no.1, p. 47-49, 1997.

Priya, K. P.; Geetham P. K. M. A co-inoculation study on the potential integrate of Azospirillum and phosphate solubilizing bacteria for improving plant growth and yield. International Journal of Food Science \& Technology, v. 3, no. 4, p. 44-49, 2015.

Qureshi, M. A.; Ahmad, M. J.; Naveed, M.; Iqbal, A.; Akhtar, N.; Niazi, K. H. Coinoculation with Mesorhizobium ciceri and Azotobacter chroococcum for improving growth, nodulation and yield of chickpea (Cicer arietinum L.). Soil \& Environment, v. 28, no. 2, p. 124-129, 2009.

Rao Bhaskara, K. V.; Charyulu, P. B. B. N. Evaluation of effect of inoculation of Azospirillum on the yield of Setaria italica (L.). African Journal of Biotechnology, v. 4, p. 989-995, 2005.

Sarker, A.; Kashem, A.; Osman, K. T. Comparative effect of city finished compost and NPK fertilizer on growth and availability of phosphorus to radish (Raphanus sativus L.) in an acid soil. International Journal of Agricultural Science, v. 2, p. 146-154, 2012.

Senthilkumar, P. K.; Sivagurunathan, P. Comparative effect on bacterial biofertilizers on growth and yield of green gram (Phaseolus radiata L.) and cowpea (Vigna sinensis Edhl.). International Journal of Current Microbiology and Applied Sciences, v. 1, no. 1, p. 34-39, 2012.

Sharma, K.; Dak, G.; Agrawal, A.; Bhatnagar, M.; Sharma, R. Effect of phosphate solubilizing bacteria on the germination of Cicer arietinum seeds and seedling growth. Journal of Herbal Medicine and Toxicology, v. 1, no. 1, p. 61-63, 2007.

Siddiqui, A.; Shivle, R.; Magodiya, N.; Tiwari, K. Mixed effect of Rhizobium and Azotobacter as biofertilizer on nodulation and production of chick pea, Cicer arietinum. Bioscience Biotechnology Research Communcation, v. 7, no. 1, p. 46-49. 2014.

Smith, S. E.; Read, D. J. Mycorhizae simbiosis. 2. ed. New York, 1997.

Swanevelder, C. J. Bambara food for Africa. South Africa: National Department of Agriculture, Republic of South Africa, 1998.

Walkley, A.; Black, I. A. An examination of the Degtjareff Method for determining soil organic matter, and a proposed modification of the chromic acid titration method. Soil Science, v. 37, no. 1, p. 29-38, 1934.

Yao, D.; Bonny, B.; Zoro, I. Preliminary observation of the variability between some morphotypes of voandzou (Vigna 
subterranea L. Verdc., Fabaceae) in Ivory Coast. Biotechnology, Agronomy, Society and Environment, v. 9, p. 249-258, 2005.

Yao, D. D.; Kouassi, K. N.; Erba, D.; Scazzina, F.; Pellegrini, N.; Casiraghi, M. C. Nutritive evaluation of the bambara groundnut landrace [Vigna subterranea (L.) Verdc. (Fabaceae)] produced in Côte d'Ivoire. International Journal of Molecular Sciences, v. 16, p. 21428-21441, 2015. https://doi.org/10.3390/ijms160921428

(CC) Attribution License, which permits unrestricted use, distribution, and reproduction in any medium, provided the original work is properly cited. 